Review article

Received: 04. July 2020;

Received in revised form: 17 . July 2020;

Accepted: 18. July 2020;

Available online: 12. December 2020
UDC 338.48:331.5(497.11 Belgrade) doi: $10.5937 /$ zrgfub2068023S

\title{
THE INFLUENCE OF TOURISM DEVELOPMENT ON THE ECONOMIC STRUCTURE OF THE POPULATION OF BELGRADE
}

\author{
Marko Sedlak ${ }^{* 1}$, Dejan Šabić*, Snežana Vujadinović ${ }^{*}$ \\ * University of Belgrade - Faculty of Geography, Belgrade
}

\begin{abstract}
The paper analyzed the impact of tourism development on changes in the employed population in the service sectors by individual activities. The aim of this paper is to point out the relationship between changes in the number of tourists and changes in the number of employed population in service activities. The area of research is limited to the territory of the city of Belgrade. It cover an area of $3.223 \mathrm{~km}^{2}$. The basic methodological procedures used for research are mathematical - statistical methods: Pearson's correlation coefficient (r), testing the significance of the correlation coefficient ( $\mathrm{t}$ test) and causal relationship (R). By applying the mentioned methods, a strong connection has been established between the growth of tourist traffic and the growth of the number of employed population in the service delivery activities on the territory of Belgrade.
\end{abstract}

Key words: Belgrade, tourist traffic, economic structure of the population, Pearson's correlation coefficient (r), causal relationship.

\section{Introduction}

The development of tourism has a great influence on the transformation of the territory. It is important segment of economic development considering the economic, environmental and sociological changes it brings to the environment. The capital cities represent a significant part of the country's tourist wealth, because in most cases they unite numerous features of their country. The great

1 Corresponding author: M. Sedlak, Belgrade; e-mail: maresedlak1@gmail.com 
influence of city tourist centers has a special significance for foreign tourist development (Вујовић, Цвијановић и Штетић, 2011).

The starting hypothesis in this paper is that the growth of tourist traffic affects the changes in the economic structure of the population of Belgrade. The territory of the research is limited to the administrative border of Belgrade, which consists of 7 urban and 10 suburban municipalities. Using mathematical - statistical methods, the connection between the growth of tourist traffic and changes in the numerical and percentage share of the employed population of Belgrade in service delivery activities will be investigated and established.

The analysis of the economic structure of the population of Belgrade includes the number of employed population in accommodation and catering service, administrative and support service activities and other service activities. Important data are also changes in the total number of working population, whose numerical parameters are single out in order to analyze changes in the percentage of the population of employees in service activities compared to the total number of employed population. Bu analyzing the percentage share of the population in the activities of providing services, it is posible to establish how the development of tourism modifies the economic structure of the population of Belgrade.

Analysis of tourist parameters at the level of Belgrade were monitored changes in the number of registered arrivals, the number of registered overnight stays and the average length of stay of tourists for the period from 2011 to 2018. An important component of this analysis is the segmentation of tourists into domestic and foreign in order to perceptions the tourist contract zone of Belgrade. The growth of these indicators, especially foreign tourists, implies positive trends in the tourism of our capital.

By applying statistical methods, the paper establishes changes in the number of employed population in servise activities depending on the growth of tourist traffic. It is based on establishing a relationship between the mentioned parameters (Pearson correlation coefficient), the share of common characteristics between sets of quantitative parameters (causal relationship) and significance level between these relationships ( $t$ test). The comparison is made individually between the number of recorded tourist arrivals (as an independent variable $X$ ) with the number of staff employed in accommodation and catering services, administrative and support service activities and other service activities (as dependent variable $\mathrm{Y}$ ). On the basis of statistically obtained values, it is posible to establish the degree of connection between the growth of tourist traffic and oscillations in the number of inhabitants employed in service activities. Using the same statistical procedures for the same time series (2011-2018), individual graphic analysis shows differences in the impact of tourist traffic on individual service activities. 


\section{Field of research and methodology}

The research area includes the territory of the city of Belgrade, which includes 7 urban and 10 suburban municipalities: Barajevo, Voždovac, Vračar, Grocka, Zvezdara, Zemun, Lazarevac, Mladenovac, Novi Beograd, Obrenovac, Palilula, Rakovica, Savski Venac, Sopot, Stari Grad, Čukarica and Surčin. The total area with the listed municipalities is $3.223 \mathrm{~km}^{2}$. Belgrade has a favorable strategic (in the past), economic, traffic, tourist, political and functional location. It originated and developed at the confluance of the Sava and the Danube river, at the contact of the Pannonian plain and the northern part of the Šumadija hills (Станковић, 2013; Станковић и Гајић, 2019).

The application of statistical methods is the framework of the research process in this paper. The basic methods used in this paper to analyze the impact of tourism development on the active population of Belgrade employed in the service delivery sectors are Pearson's correlation coefficient and causal relationship. The values of the Pearson correlation coefficient range from +1 to -1 depending on the degree of interrelationship between the examined quantitative variables. The correlation coefficient between the examined variables can be positive or negative, with gradation of bond strenght (weak, medium, strong, perfect) based on the obtained values of $r$ coefficient. The calculation of the correlation coefficient $(\mathrm{r})$, on the basis of which the data were processed by years, is performed using the formula (Bluman, 2009; Spiegel, et al., 2001; Treiman, 2014):

$$
r=\frac{n \Sigma X Y-(\Sigma X) *(\Sigma Y)}{\sqrt{\left[n \Sigma X^{2}-(\Sigma X)^{2}\right] *\left[n \Sigma Y^{2}-(\Sigma Y)^{2}\right]}}
$$

The character $\mathrm{n}$ represent the number of years during the comparison was made (in this study 8 , because the data comparison period covers the period from 2011 to 2018). The $X$ variable represent an independent variable, in this case the number of tourists, because based on changes in these values, changes in the number of employees by individual service sectors are determined and the total number of employees in service activities ( $\mathrm{Y}$ variable).

By applying this method, it is posible to examine the degree of connection between the growth of tourist traffic and changes in the number of employees in service activities. A connection has been established between the number of registered tourist arrivals by years and the total number of the population of Belgrade employed in service delivery activities. A connection has been established between the number of tourists and the number of employees in individual activities related to the service delivery activities: in accommodation and catering services, administrative and support services and other service activities. The aim of this research is to establish which service delivery activities are 
most affected by the increase in tourist traffic.

Testing the significance of the correlation coefficient is an important segment of this statistical analysis, because it represents an upgrade of the statistical procedure of the obtained values by calculating the correlation coefficient. The value of the significance level was obtained by reading, with the help of the formula the value obtained, from the F table. It is carried out in order to check the significance of the interrelation of the examined variables by the method of correlation coefficient, using a formula (Treiman, 2014):

$$
t=r \frac{\sqrt{n-2}}{\sqrt{1-r^{2}}}
$$

The causal relationship (R) indicates the percentage share of the common characteristics of the $X$ variables and the $Y$ variables. In this study, variable $X$ represents the number of registered tourists in Belgrade. The $Y$ variable represents the total number of employees in the service delivery activities and the number of employees by individual activities. The formula used to calculate the causal relationship is (Bluman, 2009; Spiegel, et al., 2001; Treiman, 2014):

$$
\mathrm{R}=r^{2} * 100
$$

The period of monitoring the connection between the mentioned two categories (tourist traffic and employees in service delivery activities) covers the period from 2011 to 2018. Data on the number of tourists and the total number of employees by activities were taken from publications that have a statistical database with the economic structure of the population and records of tourist indicators. Based on a set of data on the economic structure of the population, only those quantitative data related to service delivery activities were selected.

\section{Results and discussion}

\section{The population of Belgrade employed in service activities}

The economic structure of population is an indicator of the economic orientation of a certain territorial unit. Tourism is a modifier of the economic structure by influencing changes in the number and percentage of the active population in service activities (Девеџић, 2011).

Based on eight-year data on the total number of population employed by service sectors, changes are observed (Table 1). During the period from 2011 to 2014, the number of employed population on the territory of Belgrade is con- 
The Influence of Tourism Development on the Economic Structure of the Population of Belgrade

stantly declining. The number of employed population in Belgrade was 576.905 in 2011, 566.807 in 2012, 562.992 in 2013, while in 2014 it was 559.231. The decline in the employed population amounted to 10.098 in the period between 2011 and 2012, 3.815 between 2012 and 2013, while between 2013 and 2014 the number of employed population decreased by 3.761 . The number of employed population was 670.296 in 2015, 669.845 in 2016, 691.555 in 2017, while in 2018 there were 717.998 employed population. In 2015, the number of employed population increased by 111.065 compared to the previous year. In the following 2016, the number of employed population was 451 less than in the previous year. In the next 2 years, the number of employees increase. In 2017 the number of employed population was 21.710 higher compared to 2016, while in 2018 the number of employees was 26.443 higher compared to 2017.

In the period from 2011 to 2018, a trend of constant growth in the number of employed population in accommodation and catering services was observed (Table 1). In 2011, 9.624 workers were employed in this activity, while in 2018, this number reached 27.854. Compared to 2011, in 2018, the number of employees in accommodation and catering services was three times larger. Employee growth was performed in the following order: in 2012, the number of employees increased by 601 compared to 2011, in 2013, it increased by 169 compared to 2012 , in 2014, it increased by 331 compared to 2013, in 2015, it increased by 12.237 compared to 2014, in 2016, it increased by 773 compared to 2015, in 2017, it increased by 1.580 compared to 2016, in 2018, it increased by 2.539 compared to the previous year. The largest increase in the number of employees in the activity of accommodation and catering services was recorded between 2014 and 2015, when it increases from 10.725 to 22.962 .

The number of employees in administrative and support service activities is also in constant growth in the period from 2011 to 2018 (Table 1). In 2011, the number of employees in administrative and support service activities was 16.589, while in 2018 there were 68.006 employees in this sector. In 2012, the number of employees increased by 1.199 compared to 2011, in 2013, it increased by 4.468 compared to 2012, in 2014, it increased by 950 compared to 2013, in 2015 , it increased by 24.862 compared to 2014 , in 2016, it increased by 4.284 compared to 2015, in 2017, it increased by 3.783 compared to 2016, while in 2018, the growth in the number of employees amounted to 11.871 compared to the previous year. The largest increase in the number of employees in the performance of administrative and support service activities was recorded between 2014 and 2015, when this number increases from 23.206 (in 2014) to 48.068 (in 2015).

The number of employees in other service activities fluctuated during this period (Table 1). Compared to 2011, when the number of employees in other service activities amounted to 7.746, in 2012 it increased to 7.998. There was decline in 2013 when it amounted to 5.259, and in 2014 it was increased to 5.461. 
A drastic increase followed in 2015, when the number of employees jumped to 13.735. The number of employees in other service activities increased until 2018, when it amounted to 15.616. The increase in the number of employees by 252 in the period between 2011 and 2012 was not significant, considering the decrease in 2013 by 2.739 employees compared to 2012. in 2014, there was a slight increase of 202, and the biggest increase was in 2015, when the number of employees increased bu 8.274 compared to the previous year. In 2016, the number of employees increased by 478 compared to 2015 , in 2017 , it increased by 687 compared to 2016, while in 2018 the number of employees increased by 716 compared to the previous year.

Table 1. Employed population of Belgrade in service activities

\begin{tabular}{|c|c|c|c|c|}
\hline Year & Total employees & $\begin{array}{c}\text { Accommodation } \\
\text { and catering } \\
\text { services }\end{array}$ & $\begin{array}{c}\text { Administrative and } \\
\text { support service } \\
\text { activities }\end{array}$ & $\begin{array}{c}\text { Other service } \\
\text { activities }\end{array}$ \\
\hline 2011 & 576.905 & 9.624 & 16.589 & 7.746 \\
\hline 2012 & 566.807 & 10.225 & 17.788 & 7.998 \\
\hline 2013 & 562.992 & 10.394 & 22.256 & 5.259 \\
\hline 2014 & 559.231 & 10.725 & 23.206 & 5.461 \\
\hline 2015 & 670.296 & 22.962 & 48.068 & 13.735 \\
\hline 2016 & 669.845 & 23.735 & 52.352 & 14.213 \\
\hline 2017 & 691.555 & 25.315 & 56.135 & 14.900 \\
\hline 2018 & 717.998 & 27.854 & 68.006 & 15.616 \\
\hline
\end{tabular}

Source: Општине и региони у Републици Србији 2012., 2013., 2014., 2015., 2016., 2017., 2018., 2019., Републички завод за статистику

Based on the individual number of employed population in the activities of accommodation and catering services, administrative and support service activities and other service activities, the total number of employees in activities related to the service activities was calculated, as well as the changes in the percentage share of that population in relation to the total number of employed population in Belgrade.

The number of employees in service activities has been constantly increasing during this eight-year period (Graph 1). In 2011, 33.959 people were employed in the service sector, and due to its constant growth, in 2018 the number of employees was 111.476. In the period from 2011 to 2014, the number of employees gradually grew. The largest increase in the number of employees in service activities followed in the period between 2014 and 2015, when this number increased by 45.373 . In 2018, the number of employees in service activities was higher by 77.517 compared to 2011. 
Based on the analysis of the percentage share of the number of employees in service activities in relation to the total number of employees in all activities in Belgrade, there is an increase in the share of the population in service activities. In 2011, 5,9\% of the employed population performed jobs in service activities, $6,4 \%$ in $2012,6,7 \%$ in $2013,7 \%$ in $2014,12,6 \%$ in $2015,13,5 \%$ in $2016,13,9 \%$ in 2017 and 15,5\% in 2018. The sharp increase in the number of employees in service activities between 2014 and 2015, was also reflected in the share of employees in the total population, when it increased by $5,6 \%$. Compared to 2011 , the percentage of the employed population of Belgrade in service activities in 2018 increased by $9,6 \%$.

Graph 1. Changes in the total number of employees in service activities

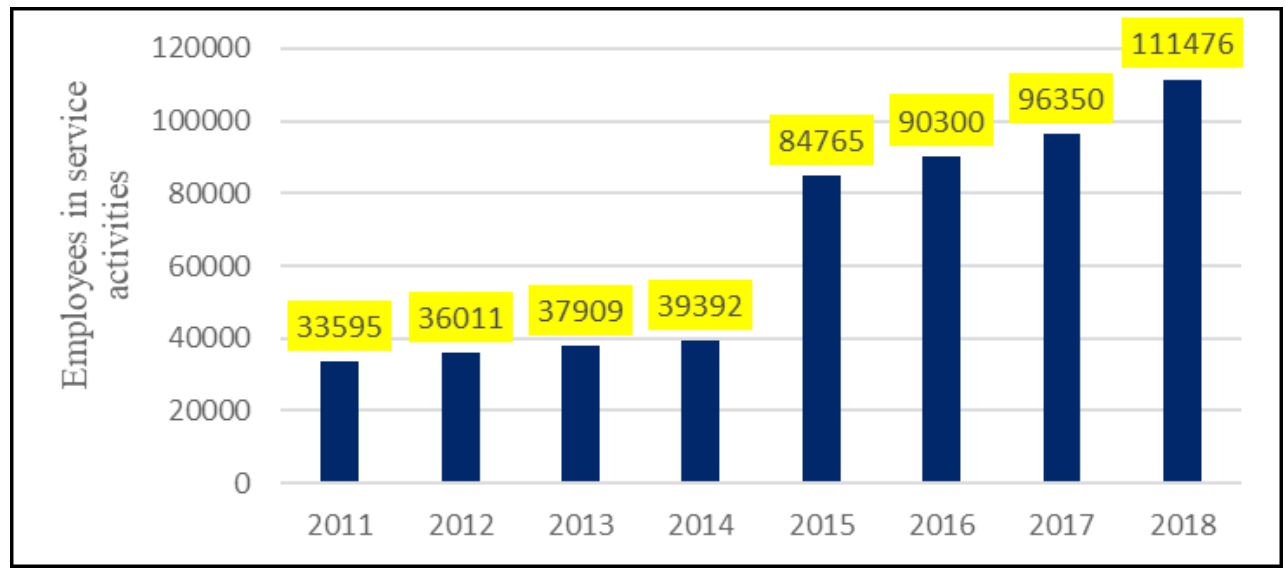

Source: Општине и региони у Републици Србији 2012-2019, Републички завод за статистику)

\section{Tourist traffic of Belgrade}

Belgrade is the largest tourist center in Serbia and this metropolis has a Balkan, European and world tourist contract zone. Belgrade is the seat of business, congress, transit and event tourism in Serbia (Јовичић, 2009; Станковић, 2013; Станковић и Гајић, 2019).

Data related to indicators of tourism development in Belgrade include an analysis for the period from 2011 to 2018, related to the total number of arrivals, overnight stays and average length of stay and their individual values broken down into domestic and foreign participants in tourism. Based on the general assessment of changes during the monitoring period, positive trends in the tourist development of Belgrade are observed. 
The number of recorded tourist arrivals in Belgrade is constantly growing (Table 2). In 2011, the city of Belgrade was visited by a total of 619.124 tourists. In 2018, this number was almost doubled (1.160.582 tourists). In the last 3 years of the series, a significant increase in tourist arrivals haas been recorded. The largest influx of tourists was recorded in 2018, when the number of arrivals increased by 125.377 compared to 2017. The number of arrivals of domestic tourits oscillated, so it is not possible to establish a connection with changes in the total number of recorded tourist arrivals. The lowest recorded number of domestic tourists was in 2014 - 155.977, while in 2012 the highest number was recorded 189.375. Unlike domestic tourists, the number of foreign tourist arrivals grows throughout the period. The number of foreign tourists was 440.347 in 2011, and 971.942 in 2018. In 2017, the largest increase in the number of foreign tourists was recorded, when 126.099 more arrivals were recorded compared to 2016.

The total number of tourist nights in Belgrade is increasing (Table 2). In 2011, 1.337.199 overnight stays were recorded, while in 2018, this number was 2.480.519. The largest increase in the number of overnight stays was recorded in 2017, which amounted to 314.324 more than in 2016. The number of overnight stays of domestic tourists varies, so that the increase in the number of overnight stays of domestic tourists was recorded between 2011 and 2012 and starting from 2014 to 2018, while the decline in overnight stays of domestic tourists was recorded from 2012 to 2014. The lowest number of overnight stays of domestic tourists was recorded in 2014 (393.156), while the highest number was in 2012 (493.531). Statistical parameters for foreign tourists indicate growth throughout the period. In 2011, the number of foreign tourist nights was 870.972, while in 2018 were recorded 2.010.749 foreign tourist nights. In 2017, the largest increase in the number of overnight stays of foreign tourists was recorded (by 297.663) compared to previous year. The largest increase in the recorded number of overnight stays of foreign tourists between 2016 and 2017 coincides with the time period in which the largest number of arrivals of foreign tourists was recorded.

Belgrade is characterized by a short average stay of tourists, which is a feature of city tourism. In the period from 2011 to 2018 the average length of stay of tourists in Belgrade is 2,1 days. The lowest average length of stay of tourists was recorded in 2014 and 2016 (2,04 days), while the highest average length of stay was in 2012 (2,17 days). Average length of stay of domestic tourists for the period form 2011 to 2018 is 2,5 days. The highest average length of stay of domestic tourists was recorded in 2011 and 2012 (2,6 days), while the shortest length of stay was in 2016 (2,3 days). Average length of stay of foreign tourists for the period from 2011 to 2018 is 1,99 days. The highest value of 2,1 days was recorded in 2018, while in other years those values were 2 days (2011, 2012, 2015, 2016 and 2017) and 1,9 days (2013 and 2014). The conclusion is that the foreign tourists stay in Belgrade for a very short time. 
The Influence of Tourism Development on the Economic Structure of the Population of Belgrade

Table 2. Tourist indicators for Belgrade from 2011 to 2018

\begin{tabular}{|c|c|c|c|c|c|c|c|c|c|}
\hline \multirow{2}{*}{ Year } & \multicolumn{3}{|c|}{ Arrivalls } & \multicolumn{3}{c|}{ Overnight stay } & \multicolumn{3}{c|}{ Lenght of stay } \\
\cline { 2 - 11 } & Total & $\begin{array}{c}\text { Dom. } \\
\text { Tourist }\end{array}$ & $\begin{array}{c}\text { Foreign } \\
\text { tourists }\end{array}$ & Total & $\begin{array}{c}\text { Domestic } \\
\text { tourist }\end{array}$ & $\begin{array}{c}\text { Foreign } \\
\text { tourist }\end{array}$ & Total & $\begin{array}{c}\text { Domestic } \\
\text { tourists }\end{array}$ & $\begin{array}{c}\text { Foreign } \\
\text { tourists }\end{array}$ \\
\hline 2011. & 619.124 & 178.777 & 440.347 & 1.337 .199 & 466.227 & 870.972 & 2,16 & 2,6 & 2,0 \\
\hline 2012. & 660.674 & 189.375 & 471.299 & 1.431 .384 & 493.531 & 937.853 & 2,17 & 2,6 & 2,0 \\
\hline 2013. & 718.943 & 182.006 & 536.937 & 1.489 .801 & 453.526 & 1.036 .275 & 2,07 & 2,5 & 1,9 \\
\hline 2014. & 753.742 & 155.977 & 597.765 & 1.535 .341 & 393.156 & 1.142 .185 & 2,04 & 2,5 & 1,9 \\
\hline 2015. & 807.607 & 157.245 & 650.362 & 1.686 .017 & 400.323 & 1.285 .694 & 2,09 & 2,5 & 2,0 \\
\hline 2016. & 913.150 & 176.087 & 737.063 & 1.867 .150 & 406.674 & 1.460 .476 & 2,04 & 2,3 & 2,0 \\
\hline 2017. & 1.035 .205 & 172.043 & 863.162 & 2.190 .474 & 432.335 & 1.758 .139 & 2,12 & 2,5 & 2,0 \\
\hline 2018. & 1.160 .582 & 188.640 & 971.942 & 2.480 .519 & 469.767 & 2.010 .749 & 2,14 & 2,5 & 2,1 \\
\hline
\end{tabular}

Source: Општине и региони у Републици Србији 2012., 2013., 2014., 2015., 2016., 2017., 2018., 2019., Републички завод за статистику

The impact of the growth of tourist traffic on the employment of the population in the service sector and in individual service activities

A cause and effect relationship has been established between changes in the number of recorded tourist arrivals and the oscillation in the number of employed staff by individual service activities (accommodation and catering services, administrative and support service activities and other service activities) and between the number of tourist arrivals and the total number of employees in service activities. Using Pearson's method for calculating the correlation coefficient, a causal relationship between the mentioned parameters and the level of significance between the examined variables was established.

The impact of tourist traffic on the total number of employed population in the service sector

Graph 2 shows the dynamics of the number of employed population in the service sector depending on the oscillation of tourist traffic. Data on the number of employed population include the total number of employed in accomodation and catering services, administrative and support service activities and other service activities. The growth in the number of tourist arrivals in Belgrade is accompanied by an increase in the number of employees in service delivery activities. The correlation coeficient with the value $r=+0.92908$ at the significance level $p \geq 0.01$, suggest a strong positive linear relationship between the investigated two parameters. The causal connection between changes in the number of registered arrivals and the total number of employed population in the service sectors is $86,32 \%$. 
Graph 2. Relationship between tourist traffic and changes in the number of employees in all service activities

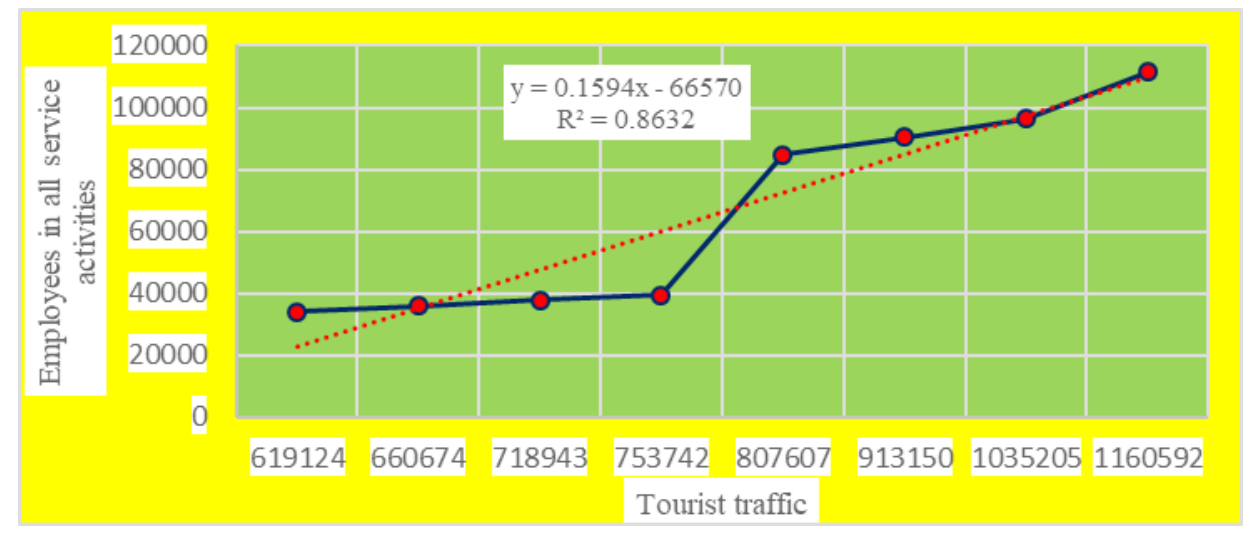

Source: Општине и региони у Републици Србији 2012-2019, Републички завод за статистику

The impact of tourist traffic on the number of employees in accommodation and catering services

Graph 3 shows the changes in the number of employed population in accommodation and catering services depending on the growth of tourist traffic. The growth in the number of tourists is reflected in the increased number of employees in this activity. The correlation coefficient with the value $r=0.93076$ at the significance level $p \geq 0.01$ suggest a strong positive linear relationship between the growth of tourist traffic and the increase of employees in accommodation and catering services. The causal connection between the examined two indicators is $86,56 \%$, which indicates a large share of common elements and a high degree of interdependence.

\section{The impact of tourist traffic on the number of employees in administrative and support service activities}

Graph 4 shows the changes in the number of employed population in administrative and support service activities as a consequence of the growth of the recorded number of tourist arrivals. A positive correlation was established between these two set of quantitative indicators, which means that the increase in the number of tourists was reflected in the increase in the number of employees in this activity. The corelation coefficient value $r=0,96026$ with the significance level $\mathrm{p} \geq 0.01$ implies a direct very strong linear relationship between the data on the growth of the number of tourist arrivals and the number of employees in 
administrative and support service activities. The causal relationship between the investigated parameters is $92,21 \%$. In relation to other service activities, the highest degree of connection is established right here.

Graph 3. Relationship between tourist traffic and employees in accommodation and catering services

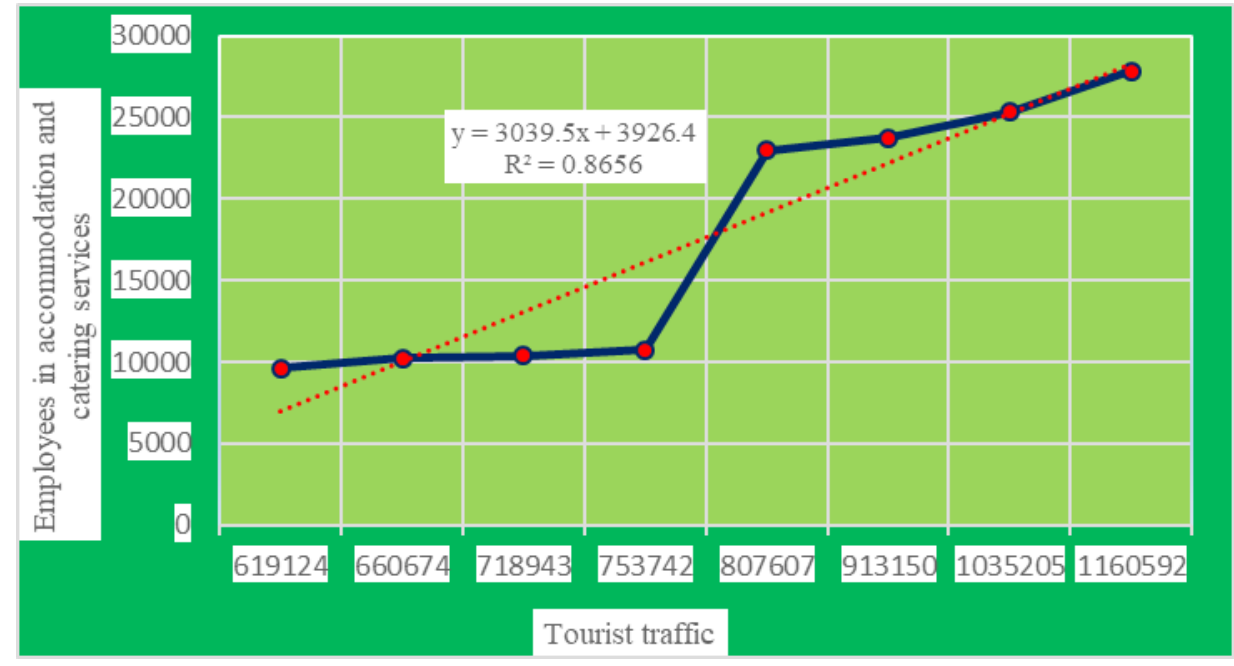

Source: Општине и региони у Републици Србији 2012-2019, Републички завод за статистику

Graph 4. The relationship between tourist traffic and the number of employees in administrative and support service activities

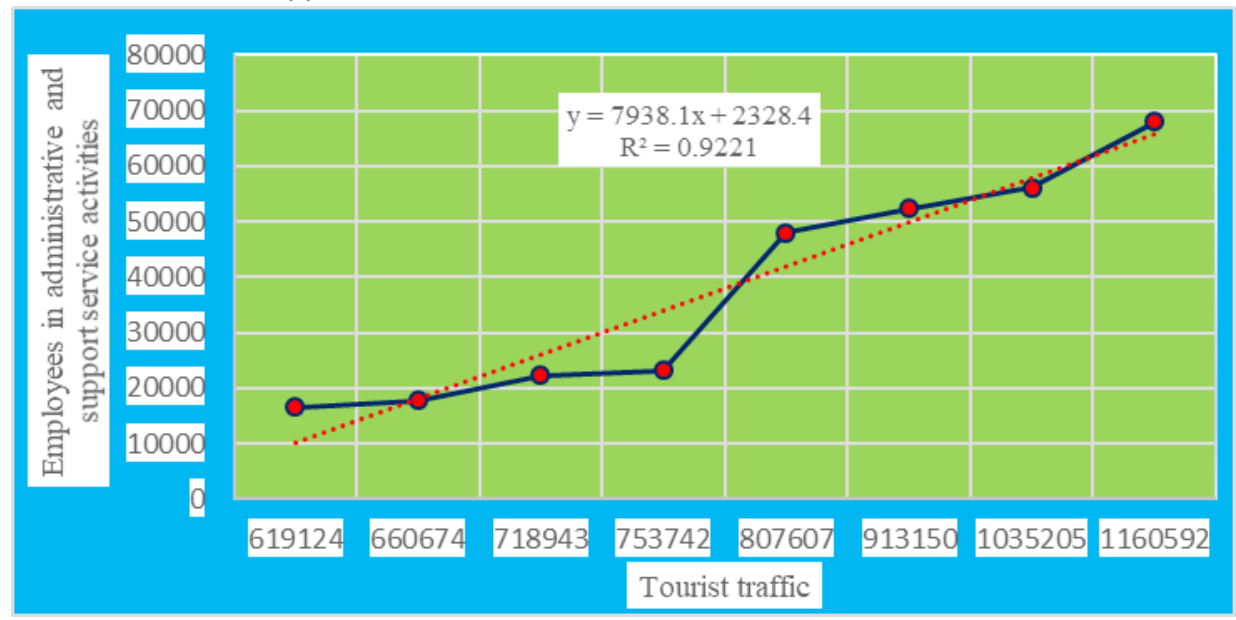

Source: Општине и региони у Републици Србији 2012-2019, Републички завод за статистику 
The impact of tourist traffic on the number of employees in other service activities

Graph 5 shows the changes in the number of employed residents of Belgrade in other service activities depending on tourist traffic. Using an identical methodological procedure, a positive correlation was established whose coefficient correlation is $r=0.8240$ at the level of significance $p \geq 0,02$. This value suggest a direct very strong linear relationship between the growth of tourist arrivals and the number of employees in other service activities. The causal relationship between these two parameters is $67,91 \%$. Compared with the previously obtained values of the correlation coefficient and the causal relationship, the lowest degree of correlation was identified between the growth of tourist arrivals and the number of employees in other service activities.

Graph 5. The relationship between tourist traffic and the number of employees in other service activities

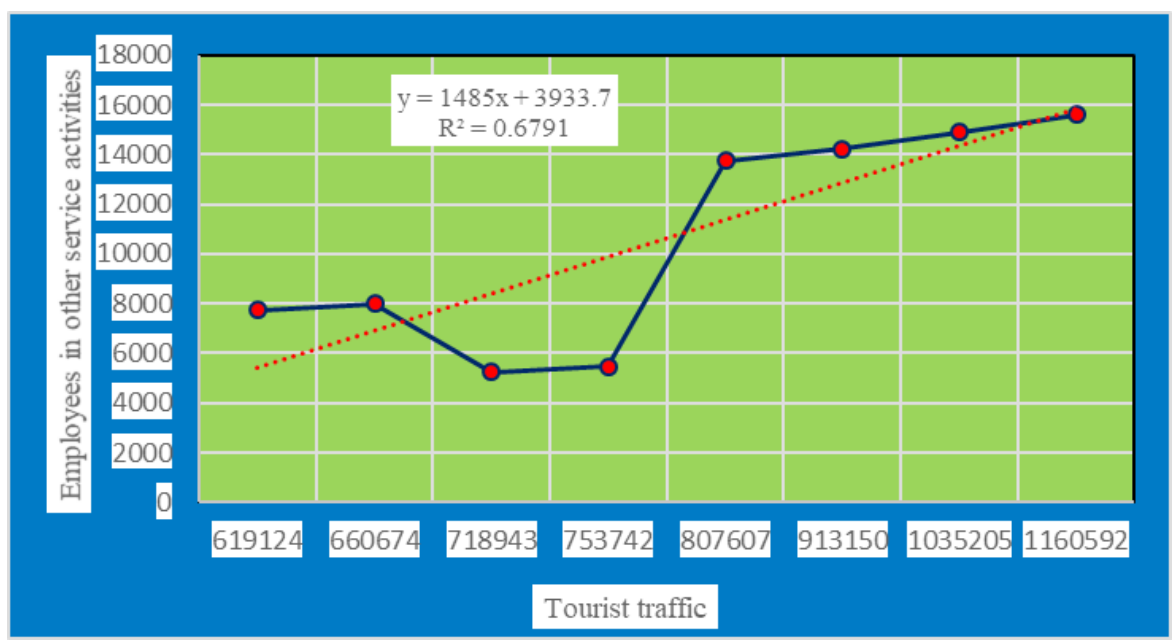

Source: Општине и региони у Републици Србији 2012-2019, Републички завод за статистику

Statistical analysis of quantitative parameters on the number of tourist arrivals and changes in employees according to activities related to the provision of services for the time series from 2011 to 2018, certain mechanizms established. Based on comparative representations of the result obtained using the method of Pearson's correlation coefficient and the value of the causal relationship, a direct very strong relationship (range $0,8 \leq \mathrm{r}<1$ ) was identified between the increase in the number of tourist arrivals and the increase in the number of employees by individual activities (accommodation and catering services, administrative and support service activities and other service activities) and the total number of employees in service activities. 
The largest relationship between the examined variables was established between the increase in the number of tourists and the increase in the number of employed staff in administrative and support service activities (with $\mathrm{r}=0,96026$ and $\mathrm{R}=92,21 \%$ ). The smallest connection (although statistically significant considering also a direct very strong linear connection) was established between the growth of tourist traffic and changes in the number of employees in other service activities $(\mathrm{r}=0,8240$ and $\mathrm{R}=67,91 \%)$. The relationship between the number of tourists and the total number of employees in all service activities implies on direct very strong relationship ( $\mathrm{r}=0,92908$ and $\mathrm{R}=86,32 \%)$.

\section{Conclusion}

An individual analysis of the economic structure of the population of Belgrade and tourist indicators for the period from 2011 to 2018, certain causal link established. In the term of employed population, an increase in the number of employed population since 2014 has been observed. The total number of employed population in service activities is also growing in both numerical and percentage share in the total number of working population (increase by $9,6 \%$ during the eight-year period). The analysis of tourist indicators established an increase in the recorded number of tourist arrivals and the number of overnight stays, while no significant progress was recorded in terms of the average length of stay of tourists. There is a trend of increasing the share of foreign tourist clientele in tourist traffic and the number of overnight stay, but it is also noticeable that average foreign tourists stay much shorter than domestic tourists.

The initial assumption was that the growth of tourist traffic is reflected in the economic structure of the population of Belgrade, increasing the numerical and percentage share of the working population in the service delivery activities. An individual analysis of the economic structure of the population of Belgrade and tourist parameters and the application of statistical methods of Pearson's correlation coefficient, testing the level of significance of the correlation coefficient and causal relationship established a very strong relationship between these two series of figures. Using these statistical models, the initial hypothesis was confirmed, which means that the growth of tourist traffic at the same time affect the growth of the working population in service activities.

By establishing a cause-and-effect relationship between tourist traffic and the working population in service activities, it is possible to predict the changes that will occur in the economic structure of the population of Belgrade. If the growth of tourist traffic continues at this pace, investments in tourism of the city will be necessary, which will affect the greater need for employees in tourism activities, which will gradually take an increasing share of service activities in the total number of employees. 


\section{References}

Bluman, A. G. (2009). Elementary statistics: A step by step approach. New York, NY: McGraw-Hill Higher Education.

Вујовић, С., Цвијановић, Д., Штетић, С (2011). Дестинаиијски конщепт развоја туризма. Београд: Институт за економику пољопривреде.

Девеџић, М. (2011). Утицај туризма на демографрски развитак: пример Црногорског приморја. Београд: Универзитет у Београду - Географски факултет.

Јовичић, Ж. (2009). Туристичка географија Србије. Београд: Универзитет у Београду - Географски факултет.

Општине и региони у Републици Србији, Београд: Републички завод за статистику, 2012-2019.

Spiegel, M. R., Schiller, J. J., Srinivasan, R. A., \& LeVan, M. (2001). Probability and statistics (Vol. 2). Mcgraw-hill.

Станковић, С. (2013). Туристичка географија Србије: правици туристичких путоваюа. Београд: Српско географско друштво.

Станковић, С., Гајић. М. (2019). Туристичка географија Србије. Београд: Универзитет у Београду - Географски факултет.

Treiman, D. J. (2014). Quantitative data analysis: Doing social research to test ideas. John Wiley \& Sons. 